\title{
Irish National Identity after the Celtic Tiger
}

A Lecture Delivered in the "New Perspectives on National Identity" Series

Liverpool, Thursday $15^{\text {th }}$ March 2012

\author{
Gerry Smyth \\ Liverpool John Moores University, England
}

Copyright (c) 2012 by Gerry Smyth. This text may be archived and redistributed both in electronic form and in hard copy, provided that the author and journal are properly cited and no fee is charged for access.

Gerry Smyth is a Reader in Cultural History at Liverpool John Moores University. He is the author of numerous books on Irish culture, including The Novel and the Nation (1997), Space and the Irish Cultural Imagination (2001), and Music in Irish Cultural History (2009). He is currently preparing his adaptation of The Brother for performance at the Edinburgh Fringe Festival, and completing a monograph entitled Treason and Betrayal in the Modern Irish Novel.

Both the biology and the life cycle of the socalled Celtic Tiger are by this stage familiar enough. From having been a drastically underachieving state throughout much of the twentieth century, the Republic of Ireland experienced a miracle during the 1990s which saw it become one of the world's most successful economies, as well as one of Europe's wealthiest countries. The term 'Celtic Tiger' was coined in 1994 by an American merchant banker working in London. The name arose from the fact that a number of factors coalesced in Ireland to create the circumstances for a period of economic growth similar in size and scale to that experienced by the Tiger economies of South East Asia, such as South Korea and Taiwan. These circumstances were many and various, but economists have pointed to two in particular: firstly, the targeting of foreign - especially American - investment; and secondly, as a complementary measure to the first, extremely attractive corporation tax rates.

Whatever the causes of the take-off into economic growth, the effects were there for all to see during the nineties and early noughties. Low unemployment and rising incomes combined to produce a buoyant economy. People could afford to buy lots more stuff, and they did buy lots more stuff: cars, more cars, holidays, more cars, houses, more houses and more cars! Ireland became a bastion of conspicuous consumption. Large-scale investment - much of it financed by the EU in the transport infrastructure saw major changes to the road and rail systems. Despite this, the cities became less and less negotiable by car, with Dublin in particular heading towards gridlock. Another change was the advent of relatively large-scale economic immigration - Chinese, Africans and Eastern Europeans; this was of course a reversal of the 
situation in which Ireland had been a net exporter of people since the Famine of the midnineteenth century. By 2007 over 10\% of people resident in the Republic were foreignborn.

Economic growth resumed after a slight downturn between 2001 and 2003, and this time it was on an unprecedented scale. In 2002 one Bank of Ireland economist forecast that by 2005 Ireland would be the second richest country in the world after Luxembourg. In 2007 one Irish bank claimed that Ireland was the second richest nation in the world, after Japan. The country's Gross Domestic Product - its GDP - outstripped those of its Eurozone neighbours such as Germany, France and the UK. It was during this time that the fate of the economy became ineluctably linked with the housing industry; construction represented over $10 \%$ of GDP and was a major employer, especially amongst the younger members of the workforce. By 2008, when Ireland's economy contracted for the first time since 1983, things still seemed to be in reasonable shape: despite Central Statistics Office forecasts of a mild recession it seemed axiomatic that after all that change, all that growth, all that stuff, Ireland's place amongst the global economic elite was guaranteed.

We all know what happened next: Credit Crunch leading to Financial Crisis leading to Global Recession in which inflated economies like Ireland have been chewed up and spat out without the blink of a Merchant Banker's eye. For it turned out that Ireland's great economic miracle was built upon very, very shaky foundations indeed; and once those foundations began to shake, they brought the whole edifice of the Irish economic miracle crashing to the ground in record time.

The emphasis on foreign investment, for example, has seriously undermined domestic entrepreneurship: this is what happens when foreign-owned companies account for over $90 \%$ of a small country's exports.

Then again, economic growth in Ireland since 1994 had always been unevenly distributed. The defenders of the Celtic Tiger had always crowed about rising living standards, and this was true to an extent; but by 2000 , the income of the poorest $20 \%$ of the population rose by less than $1 \%$; those of the middle income groups rose by $2-3 \%$; and those in the top $30 \%$ by about $4 \%$.
The property boom which had shadowed the years of growth (especially after 2003) had contributed to high inflation which in turn seriously undermined economic competetiveness. It had also led to an extreme distortion of established life and work practices: despite a huge house-building programme, fewer people than ever in the history of the state could afford to buy their own home. Those who could became dangerously over-mortgaged, and these people were some of the first to feel the pinch. Others were forced to move to towns further and further away from the major work centres: Dublin became a city region, with people having to commute from all parts of the country on a daily and a weekly basis. Ghost estates began to spring up: estates on the edges of tiny villages, with empty houses that no-one could afford to buy.

The immigration which had in some senses powered the Celtic Tiger had led in some instances to racism and xenophobia; the irony whereby Ireland - a mass exporter of economic emigrants for over a century - should begin to persecute similar populations within Ireland was lost on those who claimed that these foreigners were coming over here taking 'our' jobs.

These were, however, merely some of the more visible effects of the crash. The underlying causes were much more fundamental and much more insidious. In fact, the Celtic Tiger succumbed to what the Irish Times journalist Fintan O'Toole refers to as “a lethal cocktail of global ideology and Irish habits'. The Irish political community had sold the country to a free market ideology whose over-arching characteristic was its contempt for the sovereign governments.

The Irish banking system was particularly exposed: both corrupt and inept, the banks were merely the most visible indications of the rapid and extensive collapse of the country's economic infrastructure.

Indeed, 'corruption' and 'stupidity' became the watchwords of the analytical fallout that followed the collapse. Corruption and stupidity were endemic throughout Irish society, and everyone was implicated to some degree in the frenzy of the Tiger years. But it seems as if stupidity and corruption were especially prevalent amongst those who had been charged with overseeing the overall health and safety of 
the nation: the politicians.

While all this was going on, another cornerstone of Irish identity was also in the process of crumbling: the state-sponsored Catholic Church. The slow death of Irish Catholicism has been a bitter, harrowing process to observe. The Catholic Church had established itself as the principal moral force within Irish society after the religious and political turmoil of the seventeenth century. In the centuries that followed - but especially during the nineteenth century - the Catholic Church had arrogated to itself a range of pedagogical and pastoral responsibilities. Catholicism was an integral part of education in Ireland; indeed much of the primary-level teaching that took place in Ireland was done by religious. The church also took responsibility for orphans and young offenders, many of whom were sent to what were called Industrial Schools, a number of which were dotted around the country. Young women who got pregnant out of wedlock, or who were even suspected of being sexually active, were sent to institutions known as Magdalene Laundries, where they were forced to work in order to cleanse their sins.

Catholicism was embedded in national life after the Treaty of 1922 in which the Irish Free State was instituted; it became even more so in the Constitution drawn up in 1937 by Eamonn de Valera, which, in Article 44.1.2 (removed by the Fifth Amendment in January 1973) stated that: "The State recognizes the special position of the Holy Catholic Apostolic and Roman Church as the guardian of the Faith professed by the great majority of its citizens." Ireland was to all intents and purposes a Catholic country and the church played an extremely powerful role in all aspects of national life.

And yet, for a practice that was supposedly founded on the ideals of Love and Forgiveness, the reputation of the Catholic Church in Ireland was not what we could describe as particularly healthy. Bullying, intolerance and dogma were par for the course in what we might call 'normal' life; for those without the support of family or friends, and who were unfortunate enough to fall under the power of Catholic religious, the story was different again.

The existence of religious corruption and exploitation had been an open secret of Irish life for a long time. Individual cases that occasionally came to light could be explained away as instances of the odd 'bad egg' that you might find in any basket. With the revelation of a number of high-profile cases in the 1980s and 1990s, however, the extent of clerical exploitation - and the extent of the church's attempts to keep that exploitation secret began to emerge.

What began to emerge, in fact, was a general realization that the Industrial Schools and the Magdalene Laundries had been running a system of physical and psychological terror that operated outside the official parameters of the State; that there existed what amounted to a network of sexual exploitation - much of it pedophile in orientation - amongst Catholic clergy throughout the state; and that the Church hierarchy was aware of these practices, but - as an 'independent' organization operating freely within the state - refused to submit itself or its agents to official state sanction.

The speed with which the Catholic Church's reputation and status dissolved in Ireland is startling, especially for those such as myself old enough to remember the immediately preceding period - the 1960s and 1970s when the power and the sway of the Catholic Church was as strong as it had ever been. The priesthood was still a relatively popular career choice in Ireland in 1980; by 2010 Ireland was having to import priests from Africa and other parts of the world in order to service the dwindling number of people who still observe Catholic ritual.

Interestingly, this process of disintegration overlapped significantly with the life of the Celtic Tiger, and many people have speculated as to the relationship between the two trends. Certainly, the exposure of the Church's failures in its pastoral and spiritual mission has contributed to its steady erasure from Irish life; but it may be that this has only sped up what was happening in any case. It may be that Catholicism - like the Irish language - has become a victim of Irish pragmatism; it may be that once success and empowerment became a part of the Irish experience, a cultural practice associated with failure and subordination would be delicately but firmly jettisoned.

It's clear to see, then, that the idea of Irish national identity that obtained during the modern era suffered an extreme assault during 
the closing decades of the twentieth century and continuing on down to the present day. This was the idea that emerged during the nineteenth century as a response to certain ways of understanding Irish history as well as certain developments in Irish political, economic and cultural life: developments such as the Great Famine of the 1840s which decimated the population and which was the fountainhead of the great Irish global diaspora; developments such as the discourses of nationalism and Republicanism which fuelled the revolutionary activities underpinning the Easter Rising of 1916, the War of Independence of 1919 to 1921, and the Civil War of 1921 to 1922; and developments such as the heightened cultural activity which presaged the great wave of Irish Literary Modernism represented in the work of figures such as W.B. Yeats, James Joyce, J. M. Synge, Sean O'Casey, Samuel Beckett and Flann O’Brien.

It has become clear, in other words, that post-Celtic Tiger Ireland represents a very different prospect to the one in whose name, or against the background of which, all that activity took place. During the lifetime of the Tiger itself there was much talk in all walks of Irish life about 'new times', about the necessity of orienting the nation towards the future rather than towards the past; and, of course, the fact that the economic change coincided with the 'Peace Process' in Northern Ireland seemed to underpin this.

Before we move blithely on from that older idea of Irish national identity, however, it behoves us to consider the extent to which it ever was a reality in the first place. In his book Enough is Enough, the journalist and cultural critic Fintan O'Toole brilliantly and devastatingly exposes a series of ideas or convictions which, he says, have underpinned the dominant sense of Irish national identity since the Treaty of 1922. These ideas are:

1) that the Republic of Ireland was, indeed and in fact, a Republic;

2) that the country's elected representatives were answerable to their constituents, the people who had voted them into office;

3) that the Republic of Ireland was a functioning Parliamentary Democracy;

4) that the nation's most fundamental social, educational and healthcare needs were not really a matter for state interest, but were better off in the hands of the Catholic Church;

5) that the Celtic Tiger had turned Ireland into one of the wealthiest nations on earth.

All of these, according to O'Toole, are myths: wrong; ideas fostered and fomented by interested parties with a view to constructing a particular version of national identity that bore increasingly little resemblance to reality. The first myth concerns the idea that Ireland is a republic: in fact, for various legal and constitutional reasons, the 'Republic of Ireland' has never existed. The Constitution refers to 'Ireland' or 'Eire'. The 'Republic of Ireland', it turns out, refers to the name rather than the identity of the state. The 'Irish Republic' refers to the 32-county, all-Ireland state used in 1916 and 1919. But beyond that, the presence of powerful forces operating within and across Ireland - the Church, the banks, international finance, multinational industry, the European Union, and so on - has militated against the existence of an effective Republic.

Concerning the 'Myth of Representation', O'Toole writes that "Most Irish people seem to believe that the basic function of a politician is to 'get things done' for their constituents. They don't get things done. They clog up the system of government and create a parody of democracy.” Localism and rampant clientelism are the defining characteristics of Irish political life - not 'what you know', but 'who you know'; and this militates strongly against the idea of active citizens who are fully attuned to their rights and responsibilities as citizens.

So, the point is made: O'Toole goes on to expose the 'Myth of Parliamentary Democracy', the 'Myth of Charity', and the 'Myth of Wealth'. The last is perhaps the most damning, certainly the most counter-intuitive: What about all that stuff mentioned earlier the cars and the houses and the roads and the building and everything else? Was it not true that Ireland during the Celtic Tiger era was patently, conspicuously, a much wealthier country that it had been at any other time during its history? No, it was not true, O’Toole claims: it was a trick of statistics and wishful thinking. The idea was based on a false and damaging notion of what wealth is, where it 
resides and how it works. The mistake that most people made during the period of the Celtic Tiger was one of oldest mistakes in the book: to mistake cash for wealth. Of course, there seemed to be plenty of cash around: the preponderance of transnational export industries and the rampant inflation of property prices made for a heady atmosphere. Most commentators and economists would agree, however, that real wealth is accumulated over an extended period of time: it's manifested in fixed assets, public services, infrastructure, and potential. And against all of these criteria, Ireland's position in the table of the world's wealthiest nation was very different to the position claimed by its politicians and bankers. In fact, Celtic Tiger Ireland remained in some key respects a deeply under-developed country. Both the physical and the socio-intellectual infrastructures remained in a parlous condition. Low unemployment, low taxation and high wages contributed to the impression of prosperity; in fact, the cost of living and the expense attached to education, health care, home ownership and so on, for example, vitiated the apparent cash bonanza. What was more, nobody within government seemed willing or able to tackle the situation, so dazzled were they by the regular reports pouring in from various government offices on the country's wonderful success. So long as GDP remained the principal criterion for the definition of wealth, so long did the myth of wealthy Ireland survive.

It would be wrong to say that gains and improvements were not made in some areas of national life during the period of the Celtic Tiger; many commentators would argue, nevertheless, that the rapid, large-scale economic success which was visited upon Irish life and Irish identity during the two decades or so on either side of the millennium was inimical in a number of manifest ways. In any event, the crash of 2008 represented the return of the real with a vengeance, and it's clear to see that the waves from that momentous, ignominious fall are still crashing on the shores of the Irish consciousness today. The levels of corruption, ignorance, incompetence and sheer stupidity that precipitated economic disaster shocked everyone. Four years on, politicians, civil servants and bankers are still scrambling around trying to come to terms with the crippling pay-back regime imposed by the
European Union; ordinary people are resisting, while at the same time trying to get on with the job of finding ways to survive in such straitened times. And critics and commentators such as myself are trying to begin the task of imagining a post-Tiger dispensation - trying, that is, to imagine sustainable forms of political, economic, social and cultural identity. The question is: what does it mean - what can it mean - to be Irish in the wake of the Celtic Tiger?

There has been much talk in critical circles of a 'New Republic'; the 2008 crash represents a watershed moment - a fall, certainly, but also an opportunity to rethink the meaning of Irishness. What rough beast, we might ask, is currently slouching towards Bethlehem - or, indeed, Brussels or Berlin, or even Beijing - to be born? Of course, there would be many aspects to such a rethinking, not least the absolute and immediate reform of a political system that has time and again revealed itself to be so manifestly unfit-for-purpose.

From my perspective, however, the cornerstone of any new definition of Irish identity must be the development of a new moral vision. By this I mean a model of Irish national identity in which ideas such as responsibility and sustainability have a positive resonance; a model in which the concept of 'value' is not so completely dominated by economics; a model in which the question of what it might be right or wrong - acceptable or unacceptable - to do in any given situation is not left to politicians, bankers or civil servants.

But where is such a vision going to come from? Who's going to be responsible for its conception and articulation? Now, traditionally it has been one of the roles of the Catholic Church to provide moral guidance for the society it services; as we've already seen, however, so far from contributing to a solution to the nation's ills, the Catholic Church constitutes a significant part of the problem in modern Ireland. Fewer people than ever before are willing to accept moral guidance from an institution which has for so long, and with such energy and with such apparent imperviousness to the realities of human life, worked to inculcate such a stringently curtailed vision of sexual identity, while all the time allowing its own agents to operate outside the legal parameters of normal society.

So, the questions persist: what moral vision? 
Where's it going to come from? Who's going to be responsible for its conception and articulation? The answer is: I don't know. I do, however, at the very least claim a right to ask the question; and I would also like to claim a right to be involved in answering such a question. In a recent speech in the London School of Economics on 21 February this year, the President of Ireland Michael D. Higgins stated:

I suggest that the universities and those who labour within them are crucial in the struggle for the recovery of the public world, for the emergence of truly emancipatory paradigms of policy and research. It is not merely a case of connecting the currency, the economy and the people, it is about recovering the right to pose important questions ... what might we know, what should we do, what may we hope. It is a time to recover consideration of the public world we share, the fragile planet, for which we must have responsibility, and lodge within it a concept of intergenerational justice; and the State, civil society, communities and citizens are needed to act in concert.

I hope I'm not straying too far from my remit if I signal my acquiescence with President Higgins' point regarding the importance of universities in maintaining a public sphere where the issues currently assailing Europe in general - and, from my perspective, assailing Ireland in particular may be addressed with good will. Such a sphere, utopian though it may be, offers a role to all those people who possess a real emotional and cultural investment in both the kind of society that will have to emerge from the ruins of the Celtic Tiger, as well as the idea of Irish identity in whose name and image that society will form. This latter, moreover, encompasses all those millions, in Britain, in the US, all around the world - including myself - who no longer live in Ireland but who are still bound - emotionally and culturally to its fate.

In conclusion, maybe Ireland has been lucky; maybe two decades of madness is a reasonable price to pay if the country can reclaim its soul and become the kind of free and fair democracy that for so long, so many people hoped and imagined it would be.

Received 12 March 2012 Last version 13 March 2012 